\title{
The Influence of Wage on the Economic Development in Lithuania
}

\author{
Irena Danilevičienè $\dot{1}^{1,2}$, Boguslavas Gruževskis ${ }^{2}$ \\ ${ }^{1}$ Vilnius Gediminas Technical University, Faculty of Business Management, Department of Finance Engineering, \\ Sauletekio al. 11, LT-10223, Vilnius \\ ${ }^{2}$ Lithuanian Social Research Centre, Labour Market Research Institute, A. Goštauto st. 9, LT-01108, Vilnius \\ E-mails: ${ }^{1}$ irena.danileviciene@dsti.lt (corresponding author); ${ }^{2}$ boguslavas.gruzevskis@dsti.lt
}

Received 10 February 2017; accepted 07 April 2017

\begin{abstract}
One of the major objective of each country is to ensure the economic development. The ability to set the efficient wage allows to economic development. The systematic researches of different scientists have shown that the wage must be harmoniously related to general trends of economic development. The essence of classical economics is that lower labour costs had a positive impact on the production cost and make the product more competitive. In nowadays, economy a linear relationship occurs only partially. An open labour market, especially in welfare states, and in the long-term perspective low wage inadequate to standards of living often have a negative impact on economic development. Negative factors of economic development and wage non-compliance occurs within the worker goes from national to foreign labour market. The objective of this article is to analyze these trends in general terms with emphasis on the situation in Lithuania, where from 2008-2014 years disproportion between economic development and wage level were the highest among the European Union countries. In the article, also the possibilities of economic development for using the universal progress indicator and features of wage determination are discussed. At the end of the article are concluded, that during the analyzed period (until 2015 year) Lithuania was a country, where economic development has been stopped by the improper wage determination.
\end{abstract}

Keywords: development, gross domestic product, labour market, productivity, wage.

JEL Classification: E23, J31, O47.

Conference topic: Sustainable Economics Development.

\section{Introduction}

Nowadays the economic development is perceived as a complex phenomenon, which essence is to adapt to the changing circumstances and thus promote the economic and social regional/country's progress. One of the key aspects of economic development is the conditions of wage. For working people wage is the most important source of income, which affects their living standards, the main component of consumption and economic activities of countries. Wage reflects the person's status in society and its relation with its members. It follows that in order to analyze the possibilities of economic development in the chosen region/country, it is necessary to pay a special attention to the income in the form of wage.

In developed countries the economic development are increasingly dependent on the country's human capital and its utilization efficiency. On the other hand, especially in welfare states, the residents while choosing the work are increasingly paying attention to the quality of appropriate job and personal income. The possibilities of choice of works especially increased in open economies, such as EU, where is guaranteed the free movement of services, money and population. Therefore, dealing with issues of economic development, more attention must be given to apply the adequate wage systems. In the article are analyzed works of Leibenstein, Stiglitz, Yellen, Golnau, Markowicz etc., which showed, that the wage paid by companies must to move toward the efficient wage, the same must to be recorded at macro level between the dynamic of growth of GDP and average wage. Statistical indicators showed that for period of 2008-2014 years in this context Lithuania negatively stood out from the other EU countries, as the 10-12\% growth of productivity leads to the real wage decrease about $5 \%$, when for example in Poland the productivity during the same period increased by $17-19 \%$ and real wages also increased by $11-12 \%$.

In assessing the situation in Lithuania, we have to note that the inadequate wage determination (its low level and incompatibility with the economic results) has a negative impact on the country's social development (living standards decline, phenomenon of "working poor" and "poverty trap") and limits the economic development overt time.

(C) 2017 I. Danilevičienė, B. Gruževskis. Published by VGTU Press. This is an open-access article distributed under the terms of the Creative Commons Attribution (CC BY 4.0) License, which permits unrestricted use, distribution, and reproduction in any medium, provided the original author and source are credited. 


\section{Economic development and its factors}

Researchers are constantly exploring the factors influencing the economic development, so it is one of the main tasks of economists and objective of economic science. The development were studied by Deardorff (2006), who described the phenomenon as the transition of the great part of humanity from low-income country status to a modern, highproductivity economic level caused by economic growth, so it is necessary to take an appropriate management decisions. In the context of this theory, the competitiveness is described in several ways (Meiliené, Snieška 2010; Bruneckienė, Kilijonienė 2011; Rakauskienė, Tamošiūnienė 2013):

- the efficient use of local resources;

- high living standards;

- international trade, a strong rate of exchange, other factors of competitiveness;

- the development of the labour market relates to the higher performance rates, GDP per capita.

The evaluation of economic competitiveness is determined through the important aspects, firstly evaluating the strategic solutions of economic development according to the general criteria. Measurement is also evaluating the different sources of economic competitiveness. In the broad sense, the economic development should be understood as the degree with which the economy include the efficient economic resources and distribute them (Roemer 2014). The development requires a structural transformation of production and consumption: from low value-added, low productivity and rural activities to more productive, higher value-added activities in the services and industrial sectors in urban areas. Economic development in countries increasingly depends on human capital. The certain skills and abilities to stimulate economic growth are required (Hanushek 2013). Development - it is the process of country's economic structure transformation, which promotes the production and exports of more complex products. Economic development for the productivity growth requires using the perfect methods. This is a set of the human and physical capitals, legal system framework, institutions, the knowledge (how to act purposefully), organizational skills, GDP and income (Felipe et al. 2012).

Based on the monitoring of personal income it can be measured the economic development and to assess the existing circumstances, efforts and political consequences. There are two dimensions of possibilities measurement (Roemer 2014). The first dimension is based on the calculation of average income level include those members of society, who lives, acts and works in the stressing circumstances. The second dimension is because income inequality is caused by different efforts of individuals. In general case, here are focused on the measurement dimension, which states that the inequality of economic development exist due to the different distribution of goods. Of course, it cannot be only rely on the second dimension, because the income depends not only on the individual efforts. Economic prosperity should be measured by the public's ability to achieve the better results. Every individual has a different understanding of welfare, life expectancy, education, receive the differentiated income, so assessing the economic development perspectives of particular region we should take into account the total value of all individuals.

The country's progress and economic development can be measured in a various ways. One of the proposed methods in the universal progress indicator (further - UPI) (Fig. 1) (Kisieliauskas, Starkauskienè 2012). The indicator that is proposed by the scientists is based on the assessment through the economic, social, political and environmental perspective. It is proposed to assess the economic development quantifiably, so the development is defined as the country's progress in quantitative and qualitative terms.

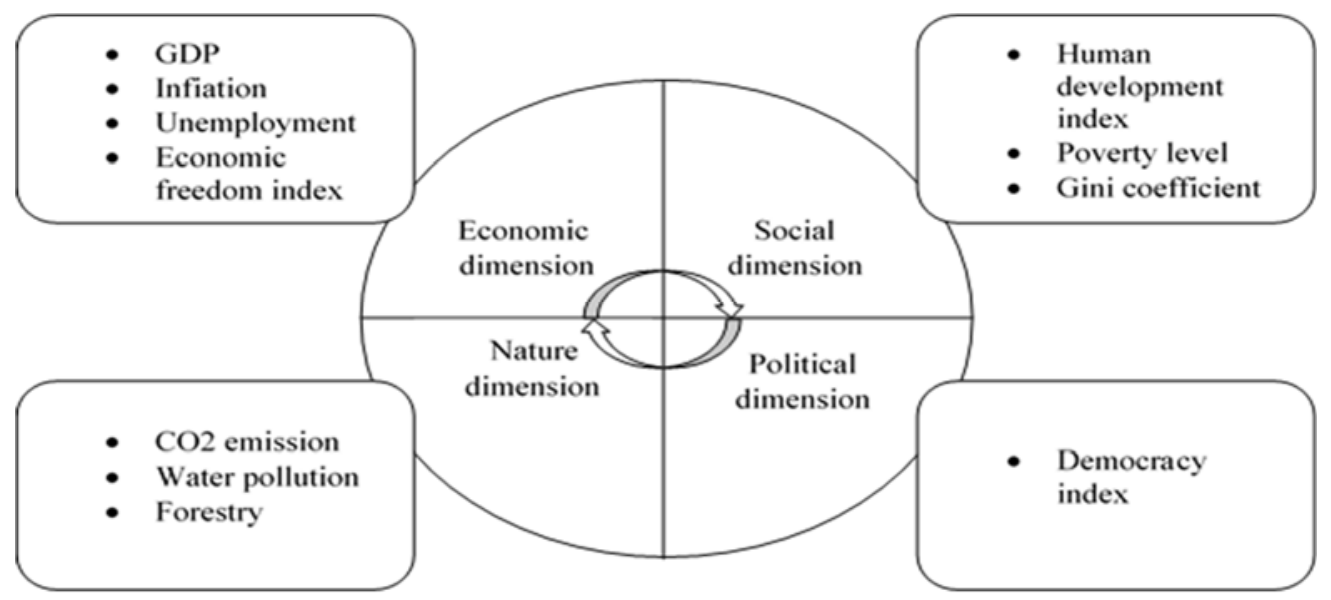

Fig. 1. The structure of universal progress indicator (Source: compiled by authors based on Kisieliauskas and Starkauskienė 2012)

It follows that for the assessment of economic development the most appropriate indicator is the GDP per capita (Felipe et al. 2012; Gaddis, Klasen 2014; Roemer 2014). GDP per capita shows the concept of justice, where an individual use is perceived as the personal income and social welfare is the average of population use. This is not only the welfare indicator, 
but also the sum of costs of economic actions. Rising GDP can be not only the consequence of progress, but also the expression of costs of economic changes (Kisieliauskas, Starkauskiene 2012). GDP reflects the average income of the population and it is use for measurement of the level of productivity (Ranci 2011).

The scientists are constantly exploring the factors that influence economic development, so the productivity analysis is one of the main tasks of economists and the objectives of economic science. Latruffe (2010) defines productivity as the ability to create value-added - product, using the available factors of production. In this context, productivity is described in several ways (Kim, Law 2012; Nowak et al. 2015), such as:

- the assumption of economic development;

- the ratio between the costs (resource utilization) and the resultant effect (the end result) and efficient management;

- one of the most important determinants of living standards.

In this context, the productivity is related to the use of the resources to the value creation. The high productivity is achieved by the efficient use of the resources. Productivity changes may result the composition of employment. These changes are affecting the measurement of the workers' contribution and therefore have an impact on the wage setting (Peluffo 2015). It follows that a proper use of labour, mainly human, resources is an essential prerequisite for ensuring economic development. Rising productivity means that the improved management tools are applied and staff are acquired the useful knowledge.

In particular, the concept of productivity explains the productivity as an important measure, which interpret invisible trends in the market and in decision-making process (Baležentis 2013). The analysis of productivity is a fundamental problem in order to improve competitiveness and creates a useful management tools for the fostering of economic development (Domańska et al. 2014). Therefore, it is proposed to measure the country's competitiveness in a various ways and one of the appropriate method is the assessment of the countrys' political, economic, social, and technological environment influence on economic progress is analysed. The authors highlight the idea that social, historical and cultural, institutional and political factors and administrative context has an important influence on the development process in the national and regional growth and companies' productivity perspective (Kim, Law 2012). The macroeconomical factors (institutional quality, openness to the international trade, geographical conditions) are fundamental determinants of the long-term productivity and growth.

Another scientist (Thirlwall 2015) offers to use the Gini coefficient for the assessment. Gini coefficient - a tool for the measurement of statistical dispersion, measuring the income or wealth inequality (Kisieliauskas, Starkauskienė 2012). As a complementary element of the evaluation can be used the human development index (further - HDI) (Roemer 2014), which aimed to assess the personal income, his education and his life expectancy. However, the index is under attack due to the low number of evaluated factors, a clear assessment methodology and the absence of the coefficients determination methodology and the underestimation of inequalities (Kisieliauskas, Starkauskiene 2012). The assessment of income helps to determine the appropriate level of economic development (Kline, Moretti 2013). The higher incomes leads to the growth of social welfare and productivity (Naudé 2013; Fajgelbaum, Redding 2014). However, at different sectors have been the various wages, so the economic activity should be constantly monitoring (Gaddis, Klasen 2014; Guzman et al. 2014). Wage inequality creates conditions for the emergence of inequality and unequal opportunities for prosperity and development achievement.

\section{The features of wage determination}

In an open economy, the wage has more complex relationship with the economic development than the classical economy. Especially in welfare states, the inadequate (low) wage can encourage workers to withdraw from economic activity to social assistance or to leave the country to gain the higher income at labour markets of other countries. Therefore, analyzing the issues of economic development the adequate attention needs to be paid also to the wage. Palidauskienè (2008) say that the wage often reflects the choice and attractiveness of location. Wage is paid not only to reflect the value of professional activity in the broader context of the labour market, but also is the part of image of profession (based on it is often formed an opinion about the status of the profession).

For the person are important two different things: raising wage and the amount of wage. From the D. Riley's point of view people are working hoping that earnings due to reward for the work and that each years it will grow a little, so the most important task of the government is periodical increasing of wage. It is necessary to decide whether it is necessary to increase the wage and how it should be done. The proponents of periodic wage raising put forward two arguments:

- people every time gain more experience, works better and therefore gain the higher wage;

- for the people working in the public sector the wage increase is the only source of economic wealth grow.

In terms of wages, we can distinguish the basic objective of the wage (Vanagas 2009) - to help implement the organization's strategic objectives and short-term objectives developing the qualified, competitive and dutiful employees and motivating them properly. In this way, the wage has always been an important economic and legal problem.

The features of wage determination has deep roots and are differentiated. The essence of wage is characterized by two theories - neoclassical, which was expressed by the A. Smith and neo Keynesian, which has been developed 
by the J. M. Keynes (Markowicz 2015). In neoclassical theory, developed by J. B. Saya, is stated that demand creates supply. In the long-term equality is reached without additional influence from the outside. Accordingly with A. Pigou the model of perfect competition in the labour market employers and employees have all the necessary information about wages and employment opportunities, makes rational decisions, there is no labour mobility restriction and labour costs are equal to labour supply and demand equality mechanism (Razmi et al. 2012). Neo Keynesian (J. M. Keynes) argue that labour force is not elastic (not flexible), wages are stable and economic equality is possible without fullemployment. In this case, people are working even at a lower wage.

Modern theories include broader hypotheses related to the existence, emergence and retention of inequality in labour market. In the modern theories are three fundamental groups of hypotheses (Knapińska 2009):

- segmentation theory, related to the structural and institutional factors, which are responsible for the emergence of inequality in the labour market;

- theories of human capital, natural unemployment and the search of labour market, which treats inequality, which is a result of long-term adaptation to labour market;

- the theory of efficient wage, which argues that the labour market inequality is a consequence of the wage stability.

In this point of view, a special attention should be paid to the efficient wage theory, because at this time, all the wages are differentiated and in order to reduce the differentiation it is necessary to establish efficient wage.

The theory of efficient wage is based on the relationship between wages and productivity. The roots of this theory go 50 years ago, when Leibenstein (1957) published a theory that has been named a feeding model. This theory is synonymous with the hypothesis about the existence of the wage-productivity curve. According to her, employer offers a wage, which guarantees the minimum wage costs falling to an efficient work. This is an efficient wage. If for the efficient wage supply will be higher than demand in the labour market will dominate involuntary unemployment. A formal base for the theory is created by R. Solow, which states that workers' efforts elasticity should be equal to 1 (Golnau 2012).

It is necessary to analyze the economy with the identical, perfectly competitive firms, each of which has a production function (1).

$$
Q=F(e(w) N),
$$

where: $N$ - the number of employees; $e$ - the employee's efforts; $w$ - the real wage.

In order to company's profit maximization here can be employed all wishing with their desired wages (Stiglitz 1981), by offering real wage $w^{*}$ (Fig. 2), which satisfies the condition that the elasticity and wage are the unity. Wage $\mathrm{w}^{*}$ is the efficient wage, which is selected by labour costs of efficiency unit minimization. This hypothesis also explains the four other labour market phenomenon (Yellen 1984):

- the severity/strength of real wage (shock, which pulls the marginal labour product and employment, but not the real wage);

- dual labour market (the assumptions, that the interaction between wage and productivity is extremely important in several economic sectors: the first - where applicable the efficiency-wage hypothesis, we found a work rating and voluntary wage, which differentiates the market, the second - where this relationship is weak or secondary, we have to monitor the full neoclassical behaviour);

- wage distribution among the employees with the same characteristics (to distribute market in accordance with the capacity to perform a specific job);

- discrimination between the observed different groups.

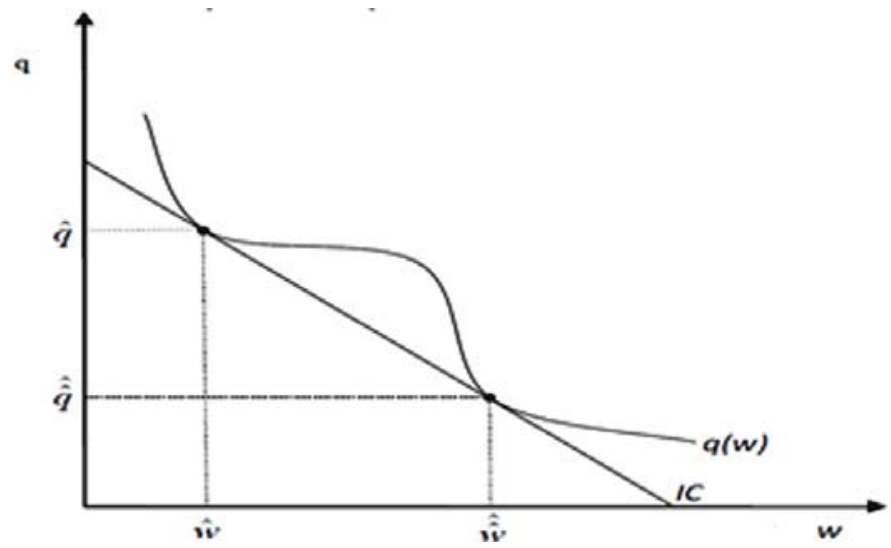

Fig. 2. Efficiency-quality model - equality between wage and productivity (Source: Stiglitz 1981) 
In small labour costs employers determine the low wage $\mathrm{w}^{\wedge}$, which is the point of intersection between the $\mathrm{q}(\mathrm{w})-$ the number of firing by the staff initiative and isocost IC (equal labour costs and fluctuations curve), when his position like $-1 / T$, where the number of firing is redundancies is $q^{\wedge}$. When labour costs rise, the point moves to $\mathrm{q}^{\wedge \wedge}$ and the higher wage $\mathrm{w}^{\wedge} \wedge$ is chosen (Yousef, Belal 2014). Then the higher wage costs are like compensation by lower recruitment, selection and training costs. In addition, it is necessary to analyse the economic development through the prism of wage.

\section{The analysis of economic development through the prism of wage}

As mentioned above, the best way to assess the perspectives of the economic development is the assessment of GDP. Figure 3 shows the amount of GDP per capita in Lithuania, Latvia, Estonia, Poland and other European countries. The basic amount - total of $28 \mathrm{EU}$ member states average (100\%).

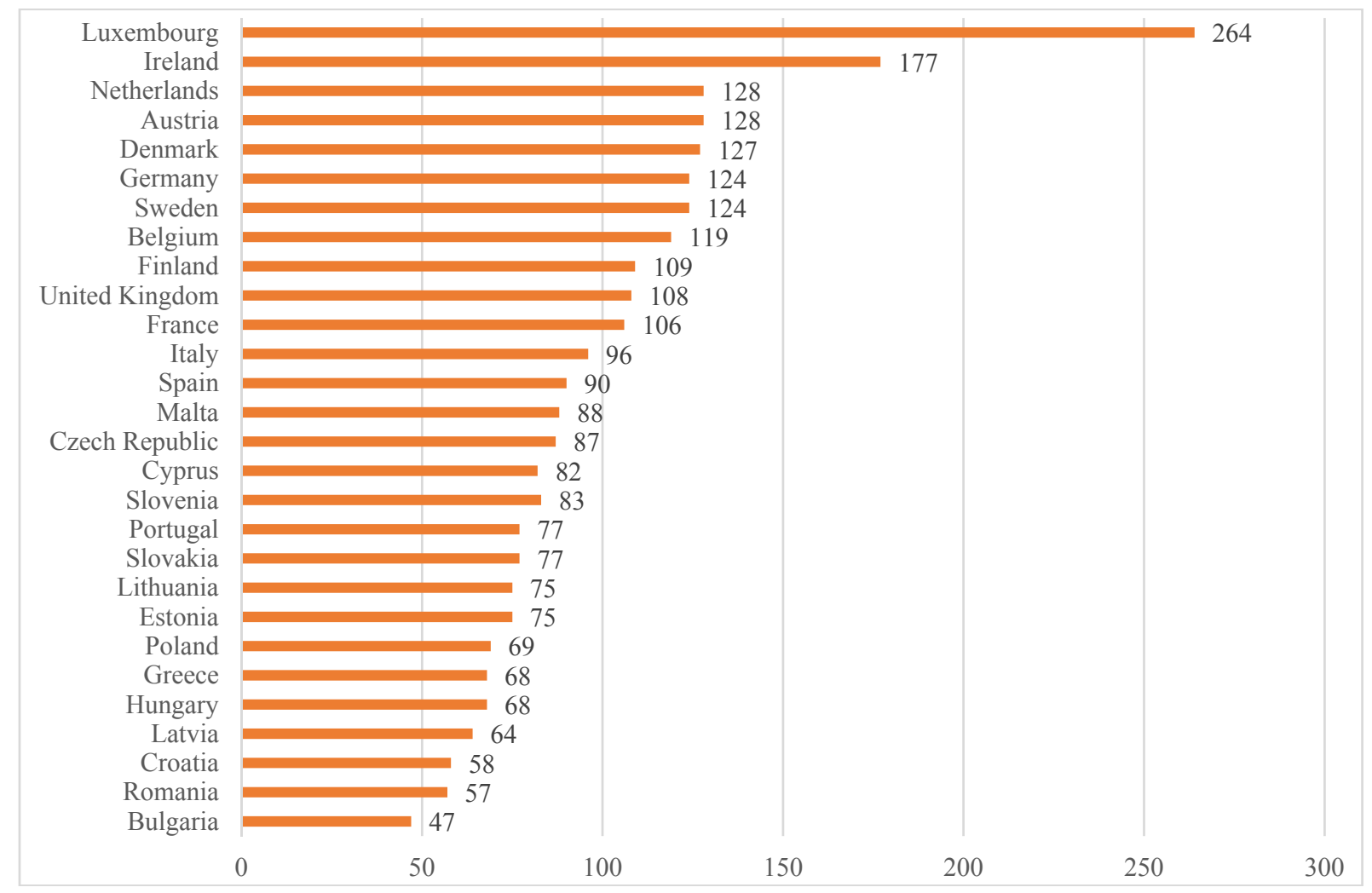

Fig. 3. GDP per capita 2015 (EU-28 = 100\%) (Source: compiled by authors based on Statistics Lithuania 2016; Eurostat 2016)

Figure 3 shows that in Lithuania (75\%), Latvia (64\%), Estonia (75\%) and Poland (69\%) GDP per capita is lower than the overall average of the 28 EU countries. This means that the economic situation in these countries is not good enough and it is necessary to take additional actions to improve the existing situation. The worst situation is in Bulgaria, Romania and Croatia, where GDP per capita is almost twice lower than the EU average. Meanwhile, the best situation is in Luxembourg (where GDP per capita is almost three times higher than the EU average) (264\%), Ireland (177\%) and the Netherlands (128\%) (about 30\% higher).

However, in terms of economic development should be taken into account not only GDP, but also the level of income and productivity. Figure 4 shows the average net annual income in EU countries in 2015 . As can be seen, the situation is quite different. Annual income in Lithuania is one of the lowest (6652 euros per year) and is almost 4 times lower than the EU 28 average. The residents of Luxembourg receive the highest average income. As can be seen, here the GDP is also the highest. However, here are disparities due to higher GDP per capita does not always mean that individuals will receive higher incomes.

A similar situation is also shown in Figure 5 whish reflects the average net wage in the period of 2015 years. The worst situation is in Lithuania, where the average wage is only 544 euros. Slightly better situation is in Latvia (601 euros) and Poland (705 euros). In the best position of the analyzed countries is Estonia, where the average wage is 832 euros. It means that although in Estonia GDP per capita is lower but there prevails better wage determination principles. 


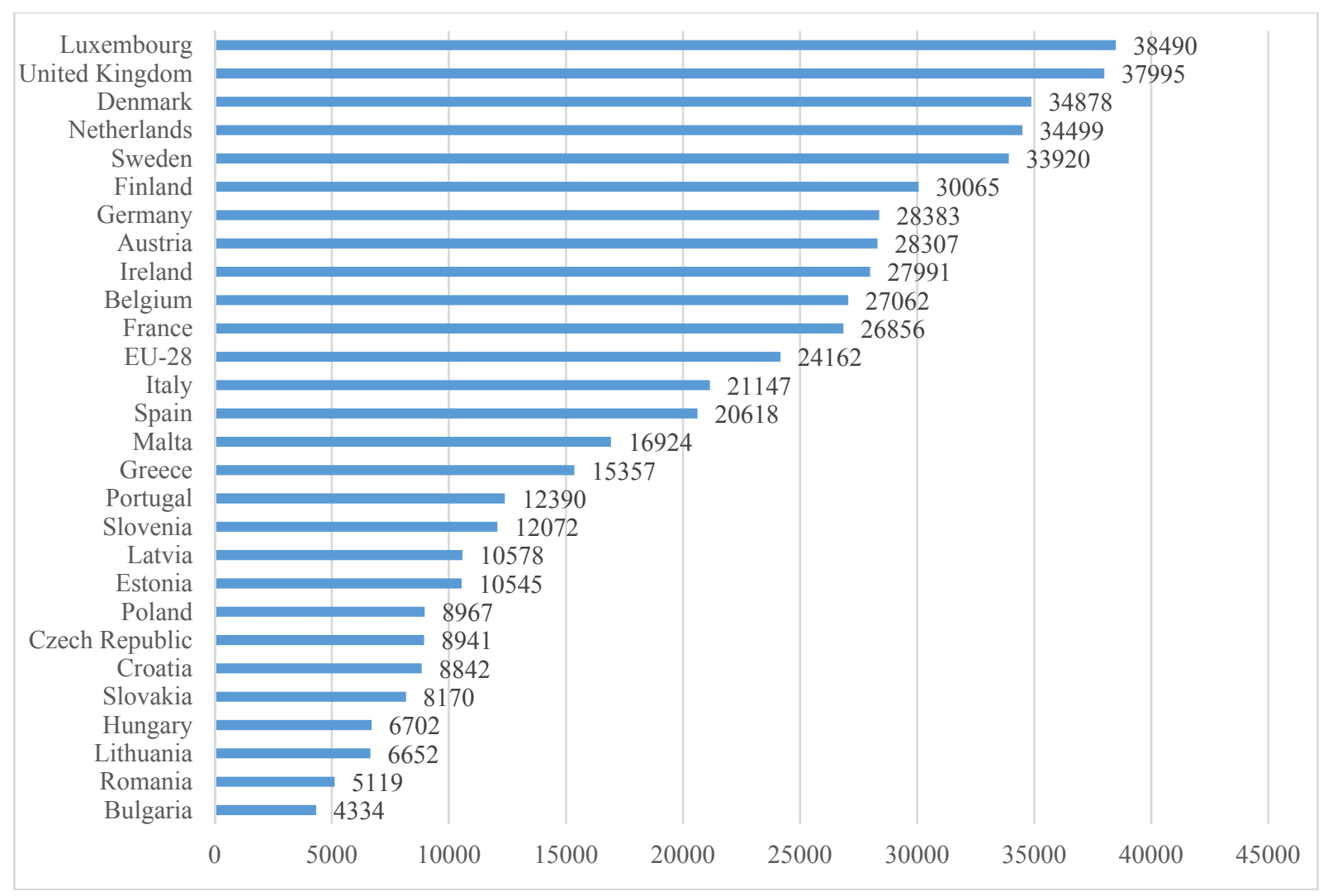

Fig. 4. The average annual income (net) in the EU countries (in euros), 2015 (single person without children) (Source: compiled by authors based on Statistics Lithuania 2016; Eurostat 2016)

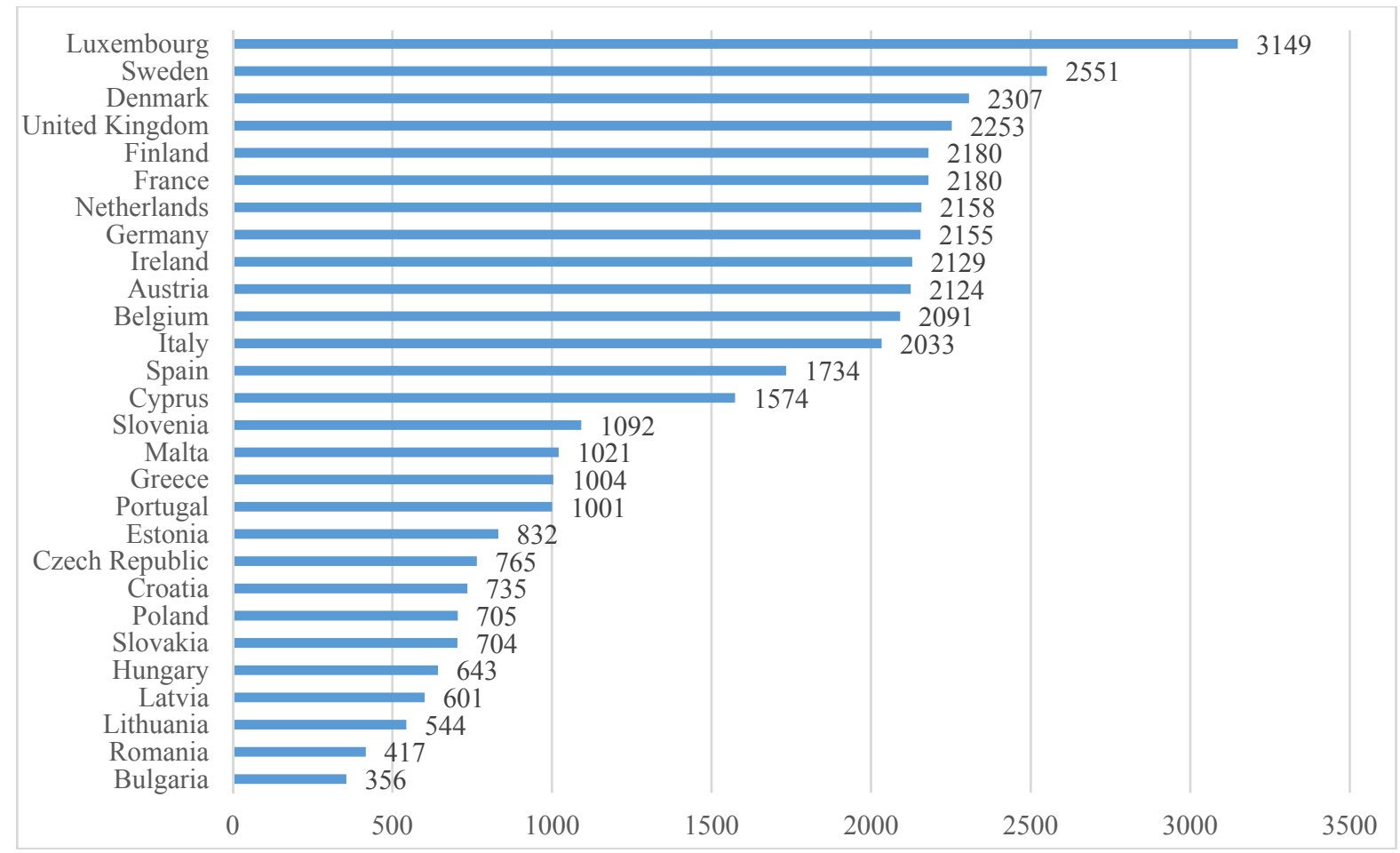

Fig. 5. Average wage (net) in the EU 2015 (euros) (Source: compiled by authors based on Statistics Lithuania 2016; Eurostat 2016)

Of course, the average annual income amounts do not reflect the real situation in the country and trying to reach a more accurate assessment quintile differentiation of income and Gini coefficient is used (Fig. 6 and Fig. 7). Quintile differentiation of income shows that in Lithuania the average of income inequality between extreme quintile in 2015 
years was even 7,5 times. In this context in Latvia and Estonia the situation is worse, because where the difference are 6,5 and 6,2 times. In Poland the situation is better, because here the income inequality is only 4,9 times. The same trends is shown in Figure 7, where is shown the results of calculation of Gini coefficient. It follows, that even with higher average income in the country is not likely that income inequality will be eliminated. In the Baltic States the income differentiation is enough high, so this should be taken into account in shaping the principles of efficient wage formation.

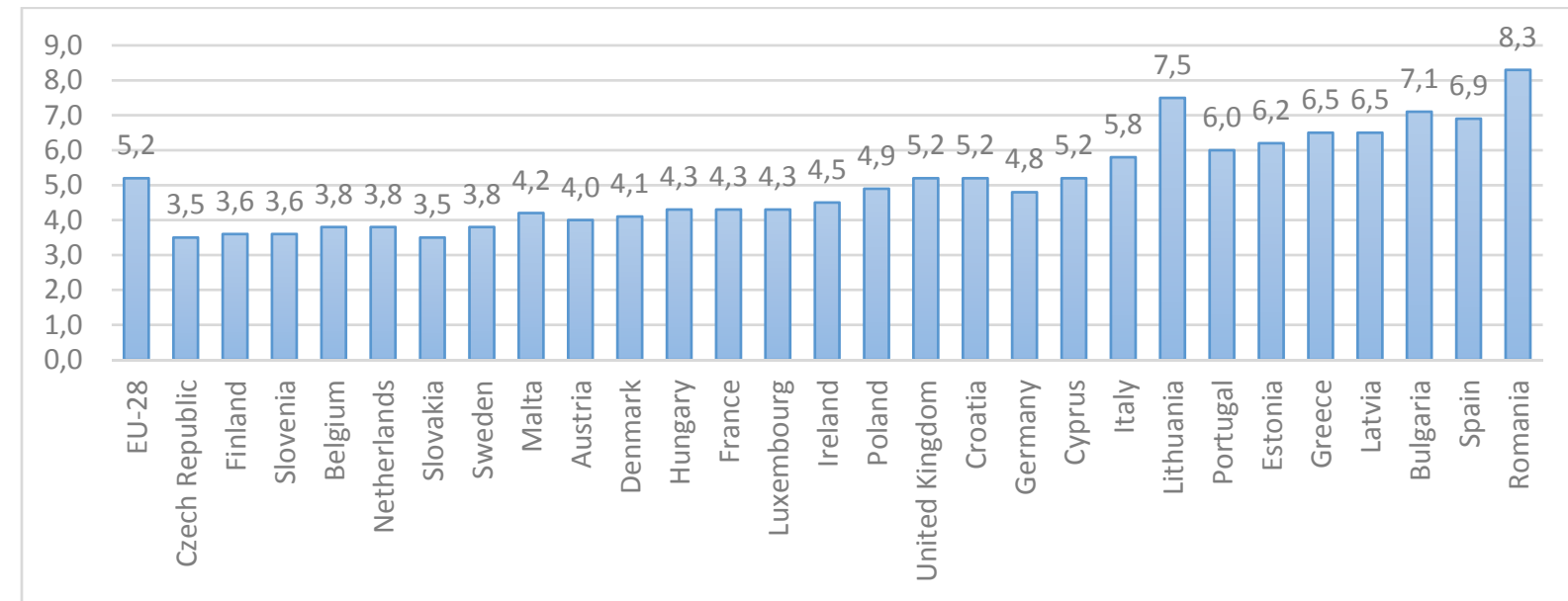

Fig. 6. The quintile differentiation of income (S80/S20) 2015 y. in EU countries (Source: compiled by authors based on Statistics Lithuania 2016; Eurostat 2016)

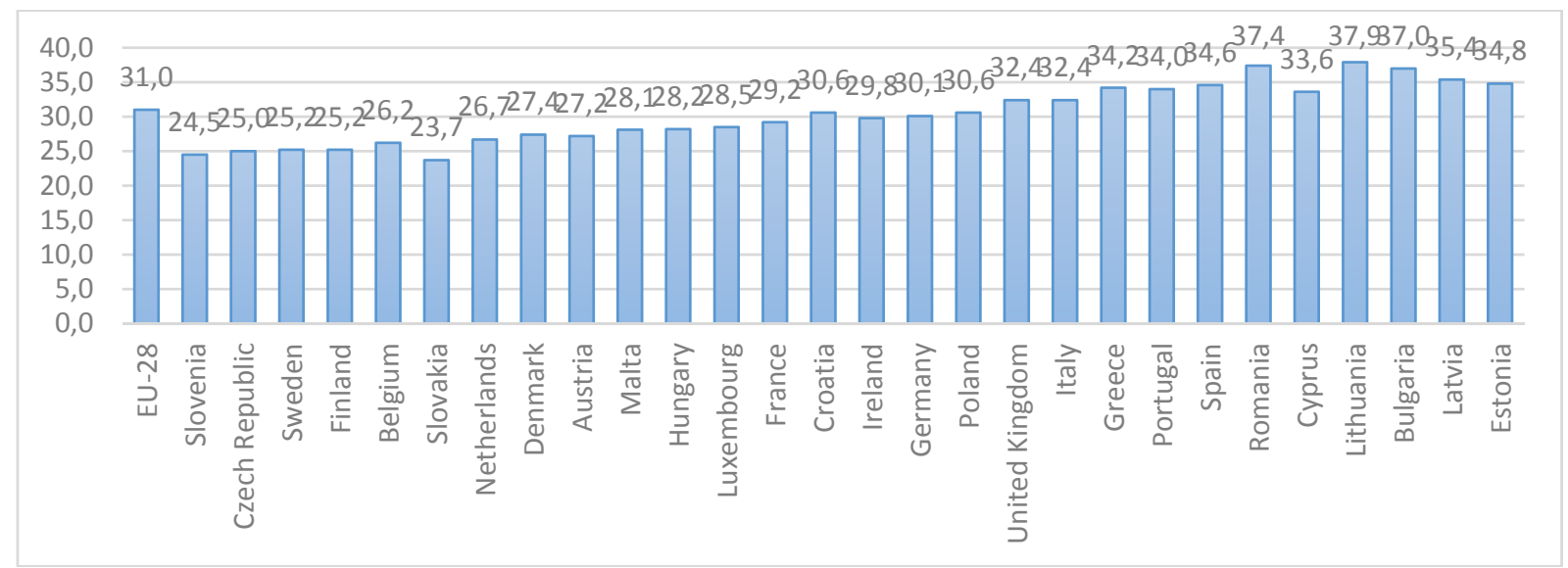

Fig. 7. The income differentiation (Gini coefficient) 2015 y. in EU countries (Source: compiled by authors based on Statistics Lithuania 2016; Eurostat 2016)

As we see, the rates of GDP and wage are closely related but among them, there is no direct connection. In order to confirm that statement it is necessary to analyze the productivity and real wage dynamic in 2008-2014 years.

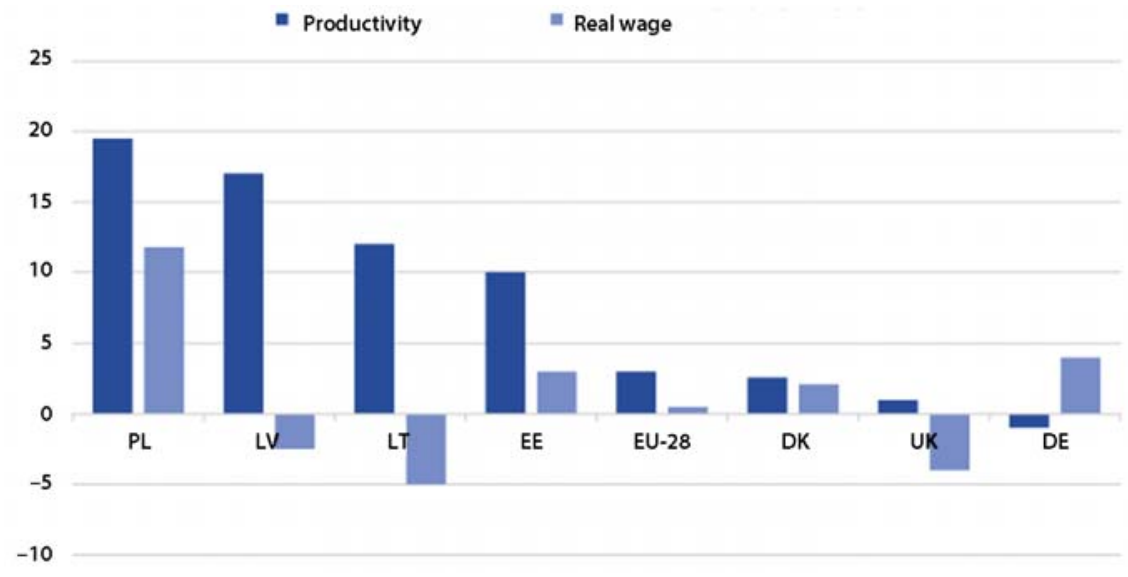

Fig. 8. The changes of productivity and real wage 2008-2014 (\%) (Source: compiled by authors based on Statistics Lithuania 2015; Eurostat 2015) 
In selected countries, the changes of productivity and wage are analyzing and it is clear that not at all countries productivity and wages growing together. In Estonia the productivity were growing twice faster than wage and in Lithuania, Latvia and the UK the productivity growth leads to the wage decline. It follows that there are exceptions and growing productivity does not always result in higher wages. Productivity can be increased also using new, improved management/working methods and of course eliminating the weakness of the labour relations in Lithuania. As shown in Figure 9, here has been identified a number of weaknesses, which shows that in Lithuania the situation is very bad. Among these factors emerged: the hiring and firing practices, firing costs, the ability to attract talent from the EU countries. The worst abilities to attract talents are only in Bulgaria.

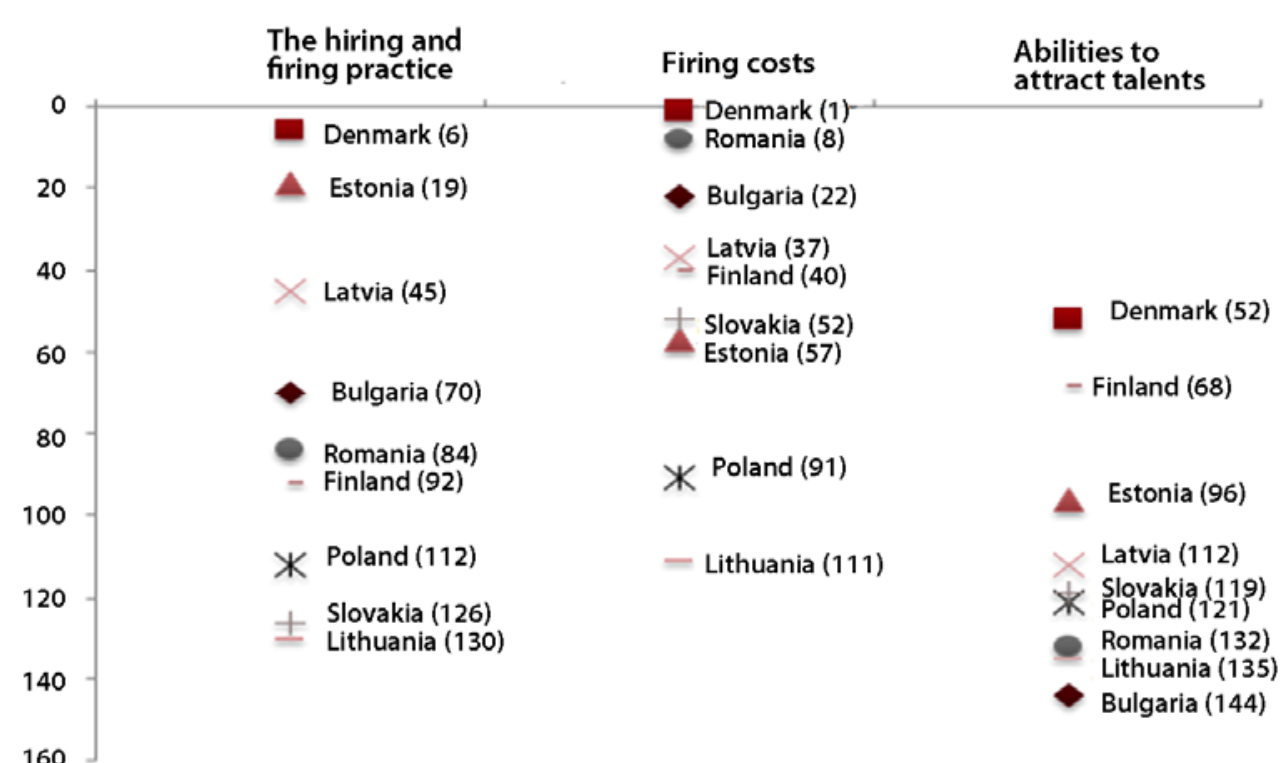

Fig. 9. The weakness of local labour relations in Lithuania

(Source: compiled by authors based on scientific literature analysis results)

In summary, the key factor of the economic development ensuring is the determination of efficient wage determination, the use of new (improved) working methods (the labour cost reduction) and increasing of ability to attract talents. Lithuania is among those countries where economic development is stopped by the improper use of labour resources and the absence of the efficient wage determination.

\section{Conclusions}

Productivity is an important measure of the economic development. The economic development requires transformation of structural production and consumption. The assessment of economic competitiveness is determined through the important aspects, also assessing the strategic economic development decisions according to the general criteria. To the evaluation of the country's progress and economic development the use of universal progress index, GDP per capita, Gini coefficient, human development index is proposed.

The wage has always been an important economic and legal problem. Analyzing the issues of economic development the adequate attention needs to be paid to the wage. In an open economy, the wage has complex relationship with the economic development. People are working hoping that earnings will be grow due to reward for the work. In welfare countries, low wages may encourage employees to withdraw from economic activity to social assistance or leave the country and search the higher incomes in other countries labour market. The higher income leads to the growth of public welfare and productivity, but in different sectors are different wages, so it is necessary to continually monitoring economic activities. Determining the efficient wage it is necessary to rely on the relationship between wages and productivity.

During the analyzed period (until 2015 year) in Lithuania GDP per capita was lower than the overall average of the 28 EU countries (only 75\%), annual income in Lithuania was one of the lowest (6652 euros per year) and is almost 4 times lower than the EU 28 average and the average wage is only 544 euros. In conclusion, Lithuania was a country where economic development has been stopped by the improper wage determination. The average wage, annual income and the Gini coefficient values were one of the poor among the Baltic countries. This means that the economic situation in these countries is not good enough and it is necessary to take additional actions to improve the existing situation. It follows, that the essential factor in ensuring the economic development is the determination of the efficient wage, improving working methods and increasing abilities to attract talents.

Based on the results of scientific literature and statistical data analysis the authors can suggest that Lithuania and other EU states should set a wage that is adequate for the work costs and must to ensure the sufficient labour productivity 
growth. Productivity can be increased using new, improved management/working methods and of course eliminating the weakness of the labour relations in the country. This would attract more employees with new knowledge, skills and workers who are motivated to achieve not only personal profit but also contribute to the overall economic value.

\section{References}

Baležentis, T. 2013. Partial factor productivity in Lithuanian family farms: the multiplier data development analysis approach, Management Theory and Studies for Rural Business and Infrastructure Development 35(1): 25-33.

Bruneckienè, J.; Kilijonienè, A. 2011. Lietuvos regionų konkurencingumo klasterinè analizè, Management Theory and Studies for Rural Business and Infrastructure Development 25(1): 60-69.

Deardorff, A. V. 2006. Deardorff's glossary of international economics. University of Michigan.

Domańska, K.; Kijek, T.; Nowak, A. 2014. Agricultural Total Factor Productivity change and its determinants in European Union countries, Bulgarian Journal of Agricultural Science 6: 1273-1280.

Eurostat. 2016. Real labour productivity per person, annual wage and GDP per capita [online], [cited 05 May 2016]. Available from Internet: http://ec.europa.eu

Fajgelbaum, P.; Redding, S. J. 2014. External integration, structural transformation and economic development: evidence from Argentina 1870-1914, National Bureau of Economic Research w20217: 1-57. https://doi.org/10.3386/w20217

Felipe, J.; Kumar, U.; Abdon, A.; Bacate, M. 2012. Product complexity and economic development, Structural Change and Economic Dynamics 23(1): 36-68. https://doi.org/10.1016/j.strueco.2011.08.003

Gaddis, I.; Klasen, S. 2014. Economic development, structural change, and women's labor force participation, Journal of Population Economics 27(3): 639-681. https://doi.org/10.1007/s00148-013-0488-2

Golnau, W. 2012. Wybrane modele w teorii płacy efektywnej, Zarządzanie i Finanse 10(4): 283-296.

Guzman, M.; Ocampo, J. A.; Stiglitz, J. E. 2014. Real exchange rate policies for economic development, initiative for policy dialogue. Columbia University.

Hanushek, E. A. 2013. Economic growth in developing countries: The role of human capital, Economics of Education Review 37: 204 212. https://doi.org/10.1016/j.econedurev.2013.04.005

Kim, S.; Law, M. T. 2012. History, institutions, and cities: a view from the Americas, Journal of Regional Science 52(1): 10-39. https://doi.org/10.1111/j.1467-9787.2011.00751.x

Kisieliauskas, J.; Starkauskienė, V. 2012. Universal Progress indicator, Applied Economics: Systematic Research 6(1): 13-24.

Kline, P.; Moretti, E. 2013. People, places and public policy: some simple welfare economics of local economic development programs, National Bureau of Economic Research w19659: 1-45. https://doi.org/10.3386/w19659

Knapińska, M. 2009. Przepływy pracowników w świetle makro- i mikroekonomicznych teorii rynku pracy. Teoretyczne i praktyczne aspekty funkcjonowania gospodarki. Szczecin: Print Group.

Latruffe, L. 2010. Competitiveness, productivity and efficiency in the agricultural and agri-food sectors, OECD Food, Agriculture and Fisheries Papers 30: 1-62.

Leibenstein, H. 1957. The theory of underemployment in backward economies, Journal of Political Economy 65(2): 91-103. https://doi.org/10.1086/257894

Markowicz, I. 2015. Statystyczna analiza przestrzennego zróżnicowania bezrobocia w Polsce, Studia Ekonomiczne 223: $247-256$.

Meilienė, E.; Snieška, V. 2010. Lietuvos pramonès konkurencingumo veiksniai eksporto politikos nuostatose, Viešoji politika ir admi nistravimas 31: 119-132.

Naudé, W. 2013. Entrepreneurship and economic development: theory, evidence and policy, evidence and policy, IZA Discussion Paper 7507: $1-20$.

Nowak, A.; Wójcik, E.; Krukowski, A. 2015. The changes in productivity of production factors in commercial farms in Poland in 2004 and 2012, Acta Scientiarum Polonorum. Oeconomia 14(3): 105-115.

Palidauskienė, J. 2008. Valstybės tarnautojų motyvavimas: lyginamasis aspektas, Viešoji politika ir administravimas 25: 7-18

Peluffo, A. 2015. Foreign direct investment, productivity, demand for skilled labour and wage inequality: an analysis of Uruguay, The World Economy 38(6): 962-983. https://doi.org/10.1111/twec.12180

Rakauskienė, G.; Tamošiūnienė, R. 2013. Šalies konkurencingumą lemiantys veiksniai, Verslas: teorija ir praktika 3: $177-187$.

Ranci, C. 2011. Competitiveness and Social Cohesion in Western European Cities, Urban Studies: 1-16. https://doi.org/10.1177/0042098010394688

Razmi, A.; Rapetti, M.; Skott, P. 2012. The real exchange rate and economic development, Structural Change and Economic Dynamics 23(2): 151-169. https://doi.org/10.1016/j.strueco.2012.01.002

Roemer, J. E. 2014. Economic development as opportunity equalization, The World Bank Economic Review 28(2): 189-209. https://doi.org/10.1093/wber/lht023

Statistics Lithuania. 2016. Wage and labour productivity data [online], [cited 10 May 2016]. Available from Internet: www.stat.gov.lt

Stiglitz, J. E. 1981. Alternative theories of wage determination and unemployment: the efficiency wage model. Princeton University, Woodrow Wilson School.

Thirlwall, A. P. 2015. Essays on Keynesian and Kaldorian Economics. Palgrave Macmillan. https://doi.org/10.1057/9781137409485

Vanagas, P. 2009. Darbo organizavimas, normavimas ir atlyginimas už darbq. Kaunas: Technologija. 370 p.

Yellen, J. L. 1984. Efficiency wage models of unemployment, The American Economic Review, 200-205.

Yousef, D.; Belal, F. 2014. Wage differential between urban and rural Palestine: the shadow of Palestinian-Israeli conflict, Working paper 839: $1-21$. 